\title{
Birds and people in semiarid northeastern Brazil: symbolic and medicinal relationships
}

Dandara Monalisa Mariz Bezerra ${ }^{1 *}$, Helder Farias Pereira de Araujo ${ }^{2}$, Ângelo Giuseppe Chaves Alves ${ }^{3}$ and Rômulo Romeu Nóbrega Alves ${ }^{4}$

\begin{abstract}
Background: At least 511 species of birds occur in the semiarid region of northeastern Brazil and many of them interact with human populations in a number of different ways, including their use in zootherapeutics and their links with local beliefs.

Objective: The present work examined these types of birds/human interactions (use in zootherapeutics and their links with local beliefs) in the semiarid region of Rio Grande do Norte State in northeastern Brazil.

Methods: Information was obtained through semi-structured interviews with 120 local residents.

Results: A total of 16 wild bird species distributed among 11 families were found to interact directly with humans, with Columbidae being the best represented family. Seven species were identified in the medicinal category, five were related to symbolic aspects, while four species were identified as being related to both categories (medicinal and symbolic).

Conclusion: The accumulated folk knowledge, beliefs, and practices involving the avifauna in the semiarid region of Brazil, whether symbolic or medicinal, demonstrated the cultural importance of this vertebrate group to local human populations and revealed a belief system intrinsically related to cynegetic practices in the region.
\end{abstract}

Keywords: Caatinga, Beliefs, Ethno-ornithology, Ethnozoology, Zootherapy

\section{Portuguese abstract}

Introdução: No semiárido do Brasil ocorrem 511 espécies de aves, algumas das quais interagem frequentemente com as populações humanas locais de diferentes formas, incluindo o uso como zooterápico e a inserção em crenças.

Objetivo: Esta pesquisa registrou as aves diretamente associadas a essas formas de interação (o uso como zooterápico e a inserção em crenças) na região semiárida do Estado do Rio Grande do Norte, Nordeste do Brasil.

Métodos: As informações foram obtidas através de entrevistas semiestruturadas aplicadas a 120 moradores locais.

Resultados: Foram registradas 16 espécies de aves silvestres distribuídas em 11 famílias, sendo Columbidae a que apresentou o maior número de representantes. Sete espécies foram indicadas apenas na categoria medicinal, cinco espécies apenas relacionadas a aspectos simbólicos e quatro foram indicadas como relacionadas a ambas as categorias (medicinal e simbólica).

(Continued on next page)

\footnotetext{
*Correspondence: dand.biologa08@gmail.com

'Departamento de Sistemática e Ecologia, Universidade Federal da Paraíba, Campus I 58051-900, Brasil

Full list of author information is available at the end of the article
} 
(Continued from previous page)

Conclusão: Os conhecimentos, crenças e práticas relacionadas à avifauna no semiárido brasileiro, seja no aspecto simbólico ou medicinal, demonstra a importância cultural que esse grupo de vertebrados representa para as populações locais, revelando um sistema de crenças que está intrinsicamente relacionado às práticas cinegéticas na região.

Palavras-chave: Caatinga, Crenças, Etnoornitologia, Etnozoologia, Zooterapia

\section{Background}

Brazil has one of the most diversified avifaunal populations in the world, with more 1,832 known species [1]. At least 511 avian species have been recorded in the semiarid region (which is dominated by steppe-savannah vegetation that is locally denominated "caatinga") $[2,3]$, and a number of these birds are used by local human populations [4-14].

Ancient relationships have been established between birds and human populations, and these animals are present in the day-to-day actions and thoughts of human cultures in many ways $[15,16]$. Birds are usually considered in terms of their roles as pets or as sources of food $[8,9,11,14,17]$, although these animals have other important forms of interaction with humans in medicinal and symbolic spheres [5,15,18-25].

Among the many types of ethno-zoological connections that exist between humans and animals are symbolicritualistic relationships that, in the case of birds, refer to omens culturally associated with these animals [26] and with the use of their body parts in magical/religious rituals $[22,24,25]$. In regards to omens, these divinations may be related to meteorological phenomena $[27,28]$ and/or have religious dimensions [22,29,30].

Birds are among the animals most frequently used in folk medicine in Brazil [6,7,19,23,31-40] and other countries of the world [20,41-49]. Zootherapeutic knowledge and practices are generally orally transmitted from generation to generation, and are associated with a wide array of cultural aspects [50]. Interrelationships between popular beliefs and zootherapy have been reported in many different localities in Brazil [6,9,31,51-54] as well as in other countries $[48,49,55,56]$. As such, the use of animalderived substances should be viewed from a cultural perspective as these medicinal practices are organized into cultural systems [57] and form through the integration of belief systems (kosmos), bodies of accumulated knowledge (corpus), and productive practices (práxis) [58].

Both the hunting and capture of bird species have been shown to affect their natural populations - with immediate and evident ecological implications $[8,9,14]$. As such, studies are needed that can reveal the different forms of interactions between people and birds and investigate questions related to their ecology, economic uses, and symbolic functions that could aid future conservation efforts [59]. Most ethnozoological research on birds has focused on their use and commerce as pets or food, while studies examining the importance of these animals as components of belief systems have been largely neglected. These types of studies are very important from a conservation point of view, however, because human perceptions of the symbolic value of an animal can be associated with either protective or destructive attitudes towards them. Within this context, the present work surveyed local human populations of hunters and ex-hunters living in the semiarid region of northeastern Brazil to identify the bird species hunted and utilized as therapeutic resources and/or cited in belief systems in order to evaluate the implications of these relationships on the conservation of the local avifauna.

\section{Methodology}

\section{Study area}

The study area included the municipalities of Caicó, São João do Sabugi, Serra Negra do Norte, and Timbaúba dos Batistas (Figure 1), located in the Seridó region of the state of Rio Grande do Norte in northeastern Brazil. The Seridó region occupies an area of $10,955 \mathrm{~km}^{2}$ [60] (approximately $20.74 \%$ of the state), most of which is covered by Caatinga dryland vegetation that has been heavily impacted by anthropogenic use and subject to desertification [61].

The regional climate is dry and hot (classified as Bswh in the Köppen system) with an average annual temperature of $27.5^{\circ} \mathrm{C}$ [62]. The rains are concentrated in the austral Summer/Fall (between January and April). The local vegetation is classified as steppe-savannah, locally caatinga denominated, with a number of distinct characteristics that causes it to be considered "Seridó caatinga" [63,64].

\section{Characterization of the target population}

The human populations in the municipalities studied are largely composed of people involved in small-scale agricultural activities such as subsistence agriculture, animal husbandry (goats, sheep, and cattle), and the service sector (e.g., small businessmen, teachers, etc.) who also undertake cynegetic activities in the region. The populations in 


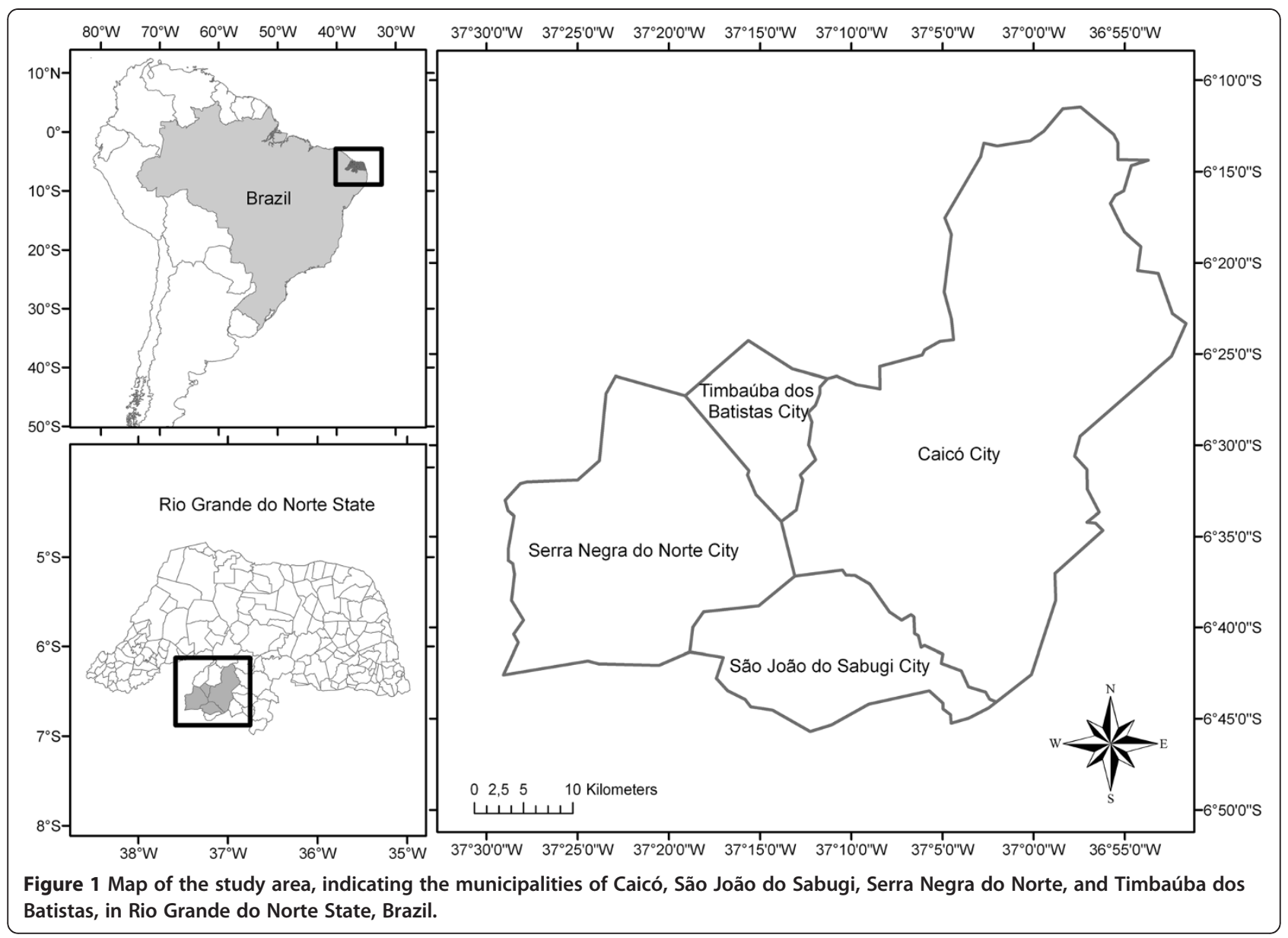

the study area consider themselves to be "sertanejos". In the categories developed by [65] to describe traditional populations, the sertanejos/vaqueiros correspond to traditional non-indigenous populations that occupy inland areas of northeast Brazil and can also advance into the semiarid caatinga region.

We interviewed a total of 120 people including hunters and ex-hunters living in the four municipalities cited above. Of these, $77.5 \%$ now live in urban areas, while the remaining $22.5 \%$ reside in rural areas. In spite of the fact that most of the interviewees lived in urban situations they still retained strong links with the rural zone, where they not only practiced their professions but also captured birds. The high percentage of people in urban areas actively using wild birds reflects their relatively recent migration from rural to urban areas as well as the transplanting of rural cultural practices to urban situations.

\section{Sampling procedures and data analysis}

Fieldwork was undertaken during the period between September/2009 and March/2010. Information was gathered through the use of interviews held with local inhabitants who utilized or interacted with wild birds in some manner.
With the aid of local community leaders we were able to identify key-informants in each municipality and the selection of interviewees then developed through the "snowball" technique [66], which consists of identifying additional informants based on recommendations of earlier interviewees.

Ethno-ornithological data was obtained through the use of semi-structured interviews [67] and direct observations [68]. The semi-structured interviews were directed towards identifying the types of birds that were captured, their forms of use and symbolic aspects associated. The interviews were undertaken individually, and most were digitally recorded; the interviews were subsequently transcribed and organized into a standardized data base. We used field notebook for notes, especially in interviews that could not be electronically recorded.

The birds cited by the interviewees were identified to the species level using published field guides [69,70], by direct sightings, and by photographic documentation during the interviews. The scientific nomenclature utilized in the present study follows the Brazilian Commission of Ornithological Records [1].

The general goals and objectives of the study were outlined to the potential informants in accessible language 
before beginning the interviews. This research project was approved by the Research Ethics Committee of the Lauro Wanderley University Hospital of the Federal University Paraíba (protocol CEP/HULW nº. 0008.0.126.000-10).

\section{Results and discussion}

Of the 120 interviewees, only 33.3\% mentioned the use of bird species in medicinal or symbolic functions, while the remainder cited their use as food sources or as pets. This low percentage may reflect a low level of use of wild birds for medicinal or symbolic practices, or it may be related to a decrease in the transmission of this type of knowledge to younger generations. Additionally, knowledge about some species was limited to a restricted number of interviewees (see Table 1), which corroborates with the hypothesis of a decrease in the rate of transmission of this type of knowledge in the regions studied.

Sixteen bird species were identified that were used in popular medicine or associated with local belief systems (Figure 2). These species belonged to 11 families, with Columbidae having the highest number of species mentioned (37.5\%) (Table 1). These species are not cited in the Brazilian list of threatened birds [71], and only in the "Least Concern" category prepared by the International Union for the Conservation of Nature [72]. There is currently no information available in the literature about the degree of conservation of the species present in the study region, and a list of locally threatened species would provide important information about cynegetic pressure on regional native birds.

The categories and subcategories used in this work are classified according to the perspective of Western science, as the local populations do not recognize any sharp distinctions between natural, supernatural, magical, religious, or medicinal spheres $[31,58]$. Using the typology proposed by Marques $[18,73]$, the present research considered the following categories and subcategories: a) medicinal: birds used in curative treatments (subcategory cures) or in preventative measures (subcategory prevention); b) symbolic: birds that humans consider capable of divining events related to the climate and the weather (subcategory climate), events that announce some misfortune (subcategory omens), or birds that are used in attempts to avoid certain problems or bring good fortune to cynegetic activities (subcategory protection).

According to the categories and subcategories proposed, 11 bird species were placed in the medicinal category (Nothura boraquira, Coragyps atratus, Cariama cristatus, Columbina minuta, Columbina talpacoti, Columbina squammata, Columbina picui, Leptotila verreauxi, Aratinga cactorum, Cyanocorax cyanopogon, and Mimus saturninus), and of these species, 10 were included in the subcategory cures, while only one (Cariama cristatus) was included in the subcategory prevention. Nine species ( $N$. boraquira,
C. cristatus, C. picui, Patagioenas picazuro, Chlorostibon lucides, C. cyanopogon, Turdus rufiventris, Icterus jamacaii, and Euphonia chlorotica) were included in the symbolic category, with four ( $N$. boraquira, C. cristatus, C. lucides, and $C$. cyanopogon) being included in the subcategory protection, one (T. rufiventris) in the subcategory climate and four (C. picui, P. picazuro, I. jamacaii, and E. chlorotica) in the subcategory omens (see Table 1).

Seven bird species (Coragyps atratus, C. minuta, C. talpacoti, C. squammata, L. verreauxi, Aratinga cactorum, and Mimus saturninus) were included only in the medicinal category, five species ( $P$. picazuro, $C$. lucides, T. rufiventris, I. jamacaii, and E. chlorotica) were related only to symbolic aspects, while four species (N. boraquira, C. cristatus, C. picui, and C. cyanopogon) were identified as belonging to both categories (medicinal and symbolic). It was noted that the medicinal and symbolic qualities attributed to the bird species cited by the hunters and former hunters were related in a general way with a system of folk beliefs transmitted down through generations.

\section{Birds as zootherapeutic resources}

Eleven bird species were cited by the interviewees as therapeutic resources in the municipalities surveyed (see Table 1). Five species had already been reported in the literature, but six were new records of medicinal birds for Brazil (Aratinga cactorum, Columbina minuta, C. talpacoti, C. picui, C. squammata, and Mimus saturninus). Summing these new species to the 47 medicinal bird species already recorded in the literature [35,57] indicates that at least 53 bird species are used in folk medicinal practices in Brazil. The uses of some of these species, such as Gallus gallus, Coragyps atratus, Nothura boraquira, and Cyanocorax cyanopogon are disseminated in many parts of Brazil [5-7,21,31-34,36,38,39,74-76]. New research initiatives concerning medicinal animals will be needed in various regions of Brazil as the true number of medicinal species must certainly exceed that presently known (see [35]). Cataloging species and their zootherapeutic uses is important because of the cultural values they represent and because this information could also be useful in terms of conserving these species. It must be emphasized, however, that there is no information available in the literature concerning the pharmacological efficiency of the therapies cited in the present study. Very few studies, in fact, have been undertaken to investigate the efficiency of any of the animals used in traditional medicines [77-79] although a limited number of workers have examined this subject e.g. [80-82]. As such, inventories of fauna-derived medicines should be subsidized with pharmacological studies that could validate (or not) the medicinal properties of animals used in folk medicine $[37,79]$. 
Table 1 Birds cited by informants in the semiarid region of Rio Grande do Norte State in northeastern Brazil as having medicinal and/or symbolic attributes: identification, categories and subcategories, uses and purposes (M- medicinal; S-symbolic), and number of citations per species

\begin{tabular}{|c|c|c|c|c|}
\hline Families/species & $\begin{array}{c}\text { Vernacular } \\
\text { name }\end{array}$ & $\begin{array}{c}\text { Category } \\
\text { (subcategory) }\end{array}$ & Uses and purposes & Citations \\
\hline
\end{tabular}

Tinamidae

Nothura boraquira Spix, 1825

White-bellied Nothura

Medicinal (cures), Symbolic (protection)

M- Administering an infusion made from the feathers of this bird will 4 meat of this bird can cure colds. S- Carrying a feather from this bird will protect a person from disagreeable events.

Carthartidae

Coragyps atratus Bechstein, 1793

Black Vulture Medicinal (cures)

M- The liver of this bird is extracted and cooked and then reduced to a powder. If this powder is added to the drink or food of an alcoholic, without that person being aware of it, they will supposedly be cured of alcoholism. Ingesting fat from the bones of this vulture will cure aching bones.

Cariamidae

Cariama cristata

Linnaeus, 1766

Red-legged

Seriema

Medicinal (prevention) Symbolic (protection)

M- Using a necklace made from the feathers of this bird will help avoid serious reactions to snake bites. S- Using a necklace made from the feathers of this bird will protect the hunter and his dog from snakebites.

Columbidae

Columbina minuta Linnaeus, 1766

Plain-breasted Medicinal (cures) Ground-Dove

Columbina talpacoti

Temminck, 1811

Columbina

squammata

Lesson, 1831

Columbina picui

Temminck, 1813

Ruddy

Ground-Dove

Medicinal (cures)

Scaled Dove Medicinal (cures)

Picui Ground- Medicinal (cures)

Dove

Symbolic (omens)

Patagioenas

picazuro

Picazuro

Symbolic (omens)

Temminck, 1813

Leptotila verreauxi

Bonaparte, 1855

White-tipped

Medicinal (cures)

Psittacidae

Aratinga cactorum Kuhl, 1820

Cactus

Trochilidae

Chlorostibon

lucidus Shaw, 1812

Glittering- Symbolic

bellied

Emerald

Corvidae

Cyanocorax

cyanopogon Wied,

White-naped

Jay

Medicinal (cures),

Symbolic (protection)

1821

Turdidae

Turdus rufiventris

Vieillot, 1818

Rufous-bellied Symbolic (climate)

Thrush

Mimidae

Mimus saturninus Lichtenstein, 1823
M- Drying the foot this bird and eating it raw, or preparing an infusion with the feces of this animal, are believed to cure colds.

M- Drying the foot this bird and eating it raw, or preparing an infusion with the feces of this animal, are believed to cure colds.

M- Drying the foot this bird and eating it raw, or preparing an infusion with the feces of this animal, are believed to cure colds.

M- Drying the foot this bird and eating it raw, or preparing an infusion with the feces of this animal, are believed to cure colds. S- The call of this bird is believed to predict disagreeable events.

S- It is believed that this bird attracts disagreeable events.

M- Eating the cooked meat of this bird will cure morning sickness during pregnancy.

M- Consuming a brew made from the meat of this bird is believed to facilitate the eruption of new teeth in children.

S- Eating the heart of this bird will make a hunter more successful.

M- If this bird is raised as a pet and fed with leftover food of a person afflicted with asthma or shortness of breath it will cure this illness. Applying an infusion made with the feathers of this bird will supposedly cure Chagas disease. S- A bird kept as a pet in the house can help prevent disagreeable events, as it is believed to be capable of foretelling them.

S- The song of this bird is believed to foretell rainfall.

1

M- Eating the cooked meat of this bird will cure morning sickness during pregnancy. 
Table 1 Birds cited by informants in the semiarid region of Rio Grande do Norte State in northeastern Brazil as having medicinal and/or symbolic attributes: identification, categories and subcategories, uses and purposes (M- medicinal; S-symbolic), and number of citations per species (Continued)

Icteridae

\begin{tabular}{|c|c|c|c|c|}
\hline $\begin{array}{l}\text { Icterus jamacaii } \\
\text { Gmelin, } 1788\end{array}$ & $\begin{array}{l}\text { Campo } \\
\text { Troupial }\end{array}$ & Symbolic (omens) & S- Keeping this bird as a pet can attract disagreeable events. & 1 \\
\hline Fringillidae & & & & \\
\hline $\begin{array}{l}\text { Euphonia } \\
\text { chlorotica } \\
\text { Linnaeus, } 1766\end{array}$ & $\begin{array}{l}\text { Purple- } \\
\text { throated } \\
\text { Euphonia }\end{array}$ & Symbolic (omens) & S- The song of this bird is believed to attract disagreeable events. & 2 \\
\hline
\end{tabular}

Medicinal uses of animals are widely disseminated throughout the world. Birds are the second most frequently used vertebrates for medicinal purposes in India [46], and a similar survey undertaken in public markets in Nigeria recorded 199 bird species used in traditional medicine [83]. Kizung et al. [41] studied the uses of birds by human populations in the Democratic Republic of Congo and reported that $11.7 \%$ of the 76 species cited by the informants were used in traditional medicinal practices. Williams et al. [84] reported that at least 354 species of birds are used for tradicional medicine in 25 African countries.

The use of birds as therapeutic resources in the present study area is based on folk knowledge that was transmitted by older members of the population. This situation follows a tendency previously noted by various authors who pointed out that zootherapeutic knowledge about birds is, as a general rule, passed down orally by older members of the community indicating the cultural value of this accumulated knowledge [5,7,21,32-34,36].

The White-naped Jay (Cyanocorax cyanopogon) had the greatest number of citations among the birds attributed with having zootherapeutic qualities in all of the municipalities studied here. The principal medicinal role of this bird, according to the informants, involves the use of live specimens to treat asthmatic problems. The interviewees reported that this malady is transferred to the bird when it is fed with the leftovers from the plate of an ailing person. This same prescription was also described in the semiarid regions of the states of Pernambuco, Paraíba, and Ceará, all of which are located in northeastern Brazil [5,6,14]. Beliefs associated with the "transfer of illnesses" to animals or plants that are placed close to a sick person or to an infected area have been reported by a number of other authors [5,6,14,36,48]. Ribeiro et al. [74], for example, noted that the simple act of sitting on a sloth skin (Bradypus spp.) was used by local populations in southern Bahia State to treat back problems. Bernitez [48] reported that interviewees from the province of Granada in Spain recommend placing a snakeskin close to the head of a patient to prevent (or treat) headaches.

In relation to the Red-legged Seriema (Cariama cristata), the informants indicated that its feathers are used as amulets to protect hunters and their dogs from snake bites. This is in agreement with the findings of Alves \& Rosa [32] and Souto et al. [40], who reported use of animal sub-products for making amulets to prevent or treat illnesses affecting humans and their domestic animals. The manners in which the White-naped Jay and the Red-legged Seriema are used reaffirms the observation that popular zootherapeutic treatments are part of a complex medical system that incorporates, among other popular health practices, rituals and magical prophylaxes such as amulets, talismans, and transference [85].

Other species cited by the interviewees included the Black Vulture (Coragyps atratus), which has widely disseminated medicinal uses in various localities in Brazil (especially in the northeastern region). This bird is popularly prescribed to treat asthma and/or alcoholism $[6,15,31,33,38,74,75]$, but was only prescribed in the study area for treating alcoholism - the same indication previously recorded by researchers in the states of Paraíba and Pernambuco [5,7]. According to the interviewees, the liver of the vulture must be extracted and roasted and then ground into a powder that is placed in the drink or food of an alcoholic - but without that person being aware of it. This type of prescription, in which the administration of a medicine derived from an animal part would only be effective if the patient did not know it was being used, has been reported by other workers $[5,7,35,48,74,75,86-88]$.

It is important to note that many zootherapeutic products are derived from birds captured for other purposes by the hunters who were interviewed. Cariama cristata (Red-legged Seriema), Nothura boraquira (White-bellied Nothura), Leptotilila varreauxi (White-tipped Dove), and the genus Columbina (Ground-Dove), for example, are hunted primarily for cynegetic purposes - but also furnish products with therapeutic uses. The use of these animal 


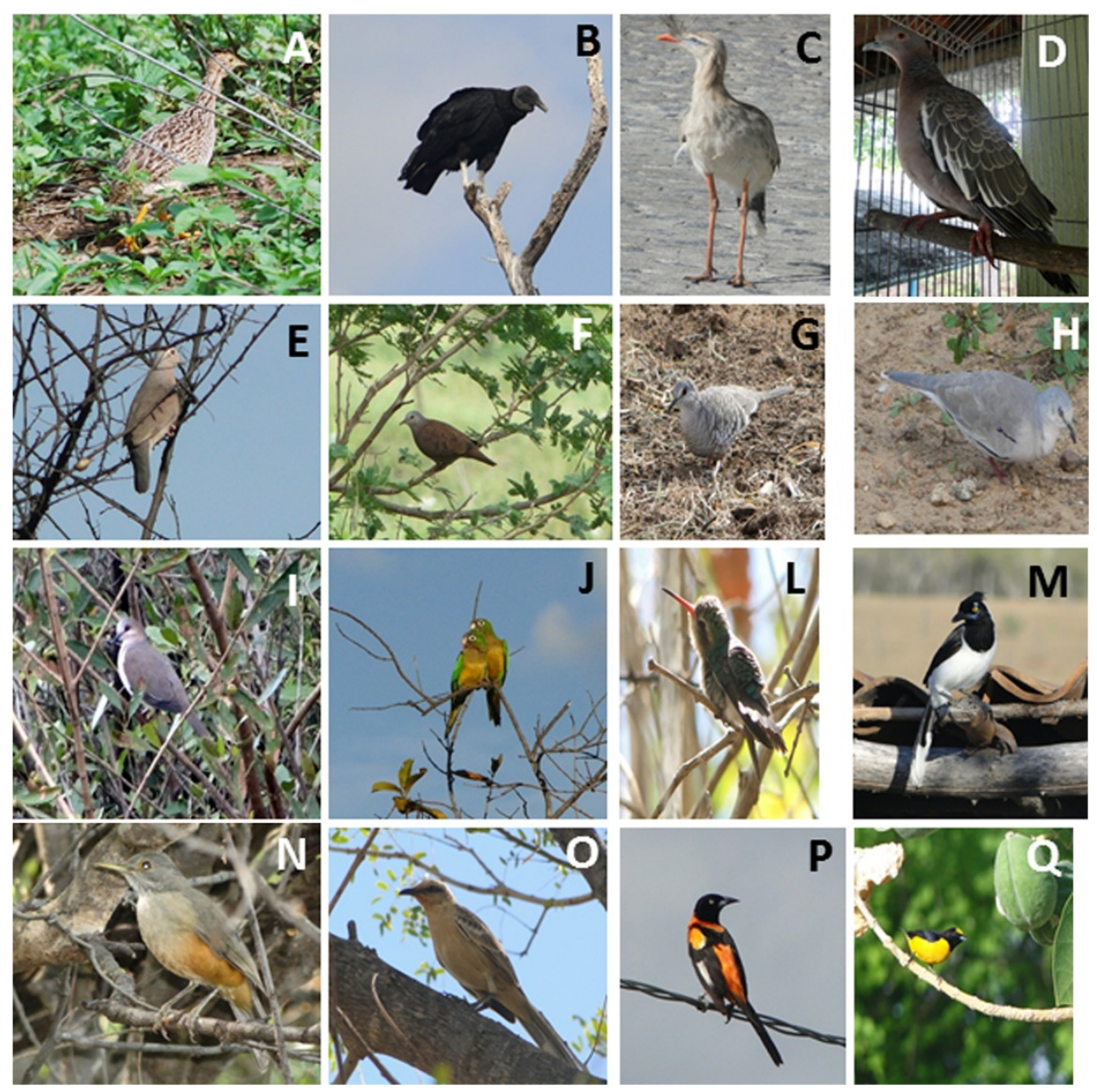

Figure 2 Bird species that were cited in popular medicine, or associated with local belief systems by interviewee in the state of Rio Grande do Norte: A- Nothura boraquira, B- Coragyps atratus, C- Cariama cristata, D- Patagioenas picazuro, E- Columbina minuta, F- Columbina talpacoti, G- Columbina squammata, H- Columbina picui, I- Leptotila verreauxi, J- Aratinga cactorum, L- Chlorostilbon lucidus, M- Cyanocorax cyanopogon, N- Turdus rufiventris, O- Mimus saturninus, P- Icterus jamacaii, Q- Euphonia chlorotica. Photos: A. John Medcraft (2009); B-Q. Dandara Bezerra $(2010,2011)$.

parts can be viewed as maximizing resource benefits from the rather limited local ecosystems [89].

\section{Birds associated with symbolic aspects}

Nine bird species in the research area were found to be associated with beliefs or superstitions (see Table 1): Euphonia chlorotica (Purple-throated Euphonia), Icterus jamacaii (Campo Troupial), Cyanocorax cyanopogon (White-naped Jay), Nothura boraquira (White-bellied Nothura), Cariam cristata (Red-legged Seriema) the hummingbird Chlorostibon lucidus (Glittering-bellied Emerald), Columbina picui (Picui Ground-Dove), Patagioenas picazuro (Picazuro Pigeon), and Turdus rufiventris (Rufousbellied Thrush). According to the interviewees, knowledge concerning these beliefs is acquired from older people or shared among friends during cynegetic activities. Although the interviewees might express certain doubts about these folk beliefs, they are considered traditional cultural elements in the region and the informants felt that it was preferable to respect them. Marques [90] observed that beliefs constitute important cultural mechanisms that serve to impose limits on the conduct and practices of community members, making certain ecological interactions socially acceptable or not.

The interviewees cited birds associated with various symbolic subcategories. These subcategories included attributes that varied from birds that supposedly bring good fortune to those that capture them, those that are considered bad omens, to those that can predict events related to the climate and the weather.

Bird vocalizations are often considered presages of natural or supernatural occurrences (ornithological divinations) and are classified according to the predicted events. The beliefs associated with the species Euphonia chlorotica (Purple-throated Euphonia) and Columbina picui (Picui Ground-Dove) in the study area were associated with the subcategory omens (birds whose calls are attributed with the power of predicting disagreeable events). A 
similar perception was documented among inhabitants of the Genipabu Environmental Protection Area in Rio Grande do Norte State, where Torres et al. [91] reported that the hummingbird Eupetomena macroura is considered to be associated with negative events. Costa-Neto [18] noted a superstition associated with the owl Tyto alba, with its calling being considered a bad omen.

In some cases, the informants indicated that they believed that certain birds if kept as pets could aid in avoiding disagreeable events because they are capable of predicting such occurrences, such as the White-naped Jay (Cyanocorax cyanopogon), which is included in the subcategory protection. In the case of this specific species, this belief may be explained in part by its characteristic ecological behavior, which according to Major et al. [92] consists of warning of the approach of any type of predator by its loud call. One informant reported that this bird would raise an alert if a snake appeared. As such, its calling serves as a type of alarm that could aid in preventing misfortune. A similar example was described by Marques [29], who reported a taboo against hunting specimens of Vanellus chilensis, a possible response to the territorial behavior of this species that uses its strident vocalizations to warn against the approximation of animals (human or otherwise).

Icterus jamacaii (Campo Troupial) and Patagioenas picazuro (Picazuro Pigeon) were considered by the interviewees consulted in this survey to be animals that can attract disagreeable events if kept as pets. According to Colding and Folke [93], taboos can be defined as unwritten social rules that regulate human behavior - informal institutions that can limit and define the use of ecosystem resources in certain contexts and thus take on conservation roles. In the cases of the species cited here, however, these beliefs were not found to be associated with any decrease in the capture rates of these animals, as the interviewees indicated that they continued to be hunted. Pagioenas picazuro is highly valued as a food source and Icterus jamacaii is commonly cited as a pet. These apparent contradictions between beliefs and usages reflect the life experiences of each individual, for as Toledo and Barrera-Bassols [94] observed, each person has his/her own kosmo-corpus-praxis complex (beliefs-knowledgepractices) that tune their experiences in response to three information sources: historically associated experiences, socially shared experiences, and individual experiences. On the other hand, the negative characteristics associated with the Purple-throated Euphonia (Euphonia chlorotica) may function to protect this species - and only five of the interviewees reported that they captured or raised these birds. This information may be useful in generating testable hypotheses related to ethno-conservation. A similar example was cited by Marques [29] and Farias et al. [30] that consisted of a total taboo protection of Fluvicola negenta (Masked Water-tyrant) encountered in northeastern Brazil.
According to popular beliefs, this species helped wash the clothes of the infant Jesus (or his mother, Our Lady, in the Catholic tradition), so that killing or capturing it was effectively prohibited by popular Catholicism.

Still within the symbolic perspective, Turdus rufiventris (Rufous-bellied Thrush) is associated with the climate subcategory (in which bird vocalizations are believed to have the power of presaging the weather and climatic events). The calls of this bird were also cited by Marques [27] and Araujo et al. [28] (who documented various bird species considered presages of rainfall in the dry northeastern region of Brazil) as being considered to predict rainfall. Marques [29] noted that birds occupy a privileged position among the faunal elements incorporated into popular Catholic religious beliefs - and in many cases this consideration is intimately related to their vocalizations. Other workers have likewise noted cultural relationships associated with bird vocalizations [18,26,28,95,96].

Beliefs associated with the species Nothura boraquira (White-bellied Nothura), Cariama cristata (Red-legged Seriema), and Chlorostibon lucidus (Glittering-bellied Emerald) in the research area were not related to their songs but rather to uses of their body parts, which were used to aid hunters by protecting them against poisonous snakes and by increasing their luck. These birds appear to have significant cultural importance to hunters, as the first two were cited within medicinal and symbolic contexts related to cures, prevention, and protection during hunting activities. Similarly, other workers have reported the use of bird body parts as amulets or talismans, including Costa-Neto [18] who cited use of the feathers of the Ferruginous Pygmy-owl (Glaucidium brasilianum) by local populations in the Amazon basin to make amulets to attract good health as well as luck in games of chance and in love. In their study of public markets in Boa Vista in northern Brazil, Pinto \& Maduro [53] recorded the popular use of body fat from Crimsonhooded Manakin (Pipra aureola) to make perfumes used to attract sexual partners. Already in study of public markets in Belém e Teresina in northern and northeast Brazil, respectively, Alves et al. [25] recorded the popular use of whole animal from Band-tailed Manakin (P. fasciicauda) to attract business; good luck/money; and perform and umbanda rituals.

In addition to the classification system adopted here, which differentiates between medicinal interactions and those of a symbolic nature, there are many close associations between these two forms of interaction. The fact that birds have a place of importance in popular medicine can be considered an important aspect of the worldview of the people directly involved in their use. Examples of the explicit intersection between symbolism and zootherapy include the belief that a certain behavior of the White-naped Jay bird (Cyanocorax cyanopogon) - 
feeding on the leftovers from the plate of a sick person can help cure that patient, the belief that the simple presence of an animal (or part of an animal, as in the case of the feathers of Cariama cristata) can protect humans and domestic animals from attacks by predators, and the belief that to obtain a cure the patient must not be aware of detailed information about the animal products he/she is ingesting (as in the necessity of hiding the powdered liver of the vulture Coragyps atratus in treating alcoholism).

As was noted in our study, birds have an enormous cultural value and are extensively used in multiple practices with various medicinal and spiritual functions. Potential conservation links with these types of interactions should be more closely examined as they can vary from species to species, and these studies must take into account factors such as habitat predation and capture for other nonmedicinal purposes - which are evident causes of at least part of the population declines noted for many species $[57,97]$. It is also important to emphasize that most of the zootherapeutic products cited here employ animal subproducts that would rarely used for any other purpose. Examples of this are Nothura boraquira and Cariama cristata and various species of the genus Columbina; these birds are hunted for food, but their feathers also serve as medicinal and symbolic subproducts (the former two species), while the feet of a number of species of the genus Columbina are used for zootherapeutic purposes. Cyanocorax cyanopogon demonstrates overlapping in the study area uses as a bird with important medicinal and symbolic attributes that is also appreciated as a pet. As such, the true motive for the cynegetic pressure on a given animal species may not be directly related to any single use.

In relation to the symbolic aspects attributed to wild birds, there were beliefs expressed by the interviewees about the vocalizations of Turdus rufiventris and Euphonia chlorotica that could stimulate positive attitudes toward them in terms of their maintenance in natural environments, as the former is believed to presage rainfall (a natural event of extreme importance to the human populations in this semiarid region), while the other species is badly thought of as a potential pet (which could protect it to some degree from anthropogenic pressure) $[9,98]$.

\section{Conclusions}

The accumulated bodies of knowledge concerning the avifauna occurring in the semiarid regions of northeastern Brazil and the use of those biological resources in both symbolic and medicinal capacities by human populations demonstrate the cultural importance of this vertebrate group. The results of the present research demonstrated that this accumulated knowledge is an integral part of the cultural heritage of those people and apparently continues to be orally transmitted to current generations.

Some of the bird species cited in the present work are not exclusively used in traditional medicine but have additional symbolic utility as well as food value and use as pets. Additionally, the fact that the interviewees know about the therapeutic effects of birds and in their symbolic values reveals a belief system that is related to cynegetic practices.

It was also observed that birds that retain significant symbolic importance can stimulate either positive or negative attitudes in humans from the perspective of biodiversity conservation. As such, it will be important to undertake specific research focusing on the diverse uses of the avifauna by human populations to determine if the cultural values assigned to them could aid in future programs directed toward biodiversity conservation.

\section{Competing interests}

The authors declare that they have no competing interests.

\section{Authors' contributions}

DMMB, HFPA, AGCA and RRNA - Writing of the manuscript, literature survey and interpretation; DMMB - Ethnozoological data; DMMB and HFPA Analysis of taxonomic aspects. All authors read and approved the final manuscript.

\section{Acknowledgments}

The authors would like to thank the Coordenação de Aperfeiçoamento de Pessoal de Nível Superior (CAPES) for their financial support; the Conselho Nacional de Desenvolvimento Científico e Tecnológico (CNPq) for awarding a productivity research grant to the third author; and especially the "sertanejos" who conceded interviews in the municipalities of Caicó, São João do Sabugi, Serra Negra do Norte, and Timbaúba dos Batistas for their hospitality, collaboration, and for kindly having shared their knowledge with this.

\section{Author details}

${ }^{1}$ Departamento de Sistemática e Ecologia, Universidade Federal da Paraíba, Campus I 58051-900, Brasil. ²Departamento de Ciências Biológicas, Universidade Federal da Paraíba, Campus I 58051-900, Brasil. ${ }^{3}$ Departamento de Biologia, Universidade Federal Rural de Pernambuco, Rua Manoel de Medeiros, S/N, Dois Irmãos, Recife 52171-900, Pernambuco. ${ }^{4}$ Departamento de Ciências Biológicas e da Saúda, Universidade Estadual da Paraíba, Paraíba 58109-753, Brasil.

Received: 24 August 2012 Accepted: 28 December 2012

Published: 8 January 2013

\section{References}

1. Comitê Brasileiro de Registros Ornitológicos (CBRO): Lista de Aves do Brasil.; 2011. http://www.cbro.org. br

2. Silva JMC, Souza MA, Bieber AGD, Carlos CJ: Aves da caatinga: status, uso do habitat e sensitividade. In Ecologia e conservação da caatinga. Edited by Leal IR, Tabarelli M, Silva JMC. Recife: Ed. Universitária da UFPE; 2003:237-274.

3. Albuquerque UP, Araujo EL, El Deir ACA, Lima ALA, Souto A, Bezerra BM, Ferraz EMN, Freire EMX, Sampaio EVSB, Las-Casas FMG, Moura GJB, Pereira GA, Melo JG, Ramos MA, Rodal MJN, Schiel N, Lyra-Neves RM, Alves RRN, Azevedo-Júnior SM, Telino Júnior WR, Severi W: Caatinga Revisited: ecology and conservation of an important seasonal Dry Forest. The Scientific World Journal 2012, 2012:1-18.

4. Farias GB, Alves AGC: Ethno-ornithological nomenclature and classification in Três Ladeiras District, Igarassu, PE, Brazil. Revista Brasileira de Ornitologia 2007, 15:358-366.

5. Alves RNN, Lima HN, Tavares MC, Souto WMS, Barboza RRD, Vasconcellos A: Animal-based remedies as complementary medicines in Santa Cruz do Capibaribe, Brazil. BMC Complementary and Alternative Medicine 2008, $8: 1-9$. 
6. Alves RRN, Barbosa JAS, Santos SLD, Souto WMS, Barboza RRD: Animalbased remedies as complementary Medicines in the semi-arid region of Northeastern Brazil. Evidence-based Complementary and Alternative Medicine 2009, 3:1-13.

7. Alves RRN, Neto NAL, Brooks SE, Albuquerque UP: Commercialization of animal-derived remedies as complementary medicine in the semi-arid region of northeastern Brazil. J Ethnopharmacol 2009, 124:600-608.

8. Alves RRN, Mendonça LET, Confessor MVA, Vieira WLS, Lopez LCS: Hunting strategies used in the semi-arid region of northeastern Brazil. J Ethnobiol Ethnomed 2009, 5:1-12.

9. Alves RRN, Nougueira EEG, Araujo HFP, Brooks SE: Bird-keeping in the Caatinga, NE Brasil. Hum Ecol 2010, 38:147-156.

10. Barbosa JAA, Nóbrega VA, Alves RRN: Aspectos da caça e comércio ilegal da avifauna silvestre por populações tradicionais do semiárido paraibano. Revista de Biologia e Ciências da Terra 2010, 10:39-49.

11. Fernandes-Ferreira H, Mendonça SV, Albano C, Ferreira FS, Alves RRN: Comércio e criação de aves silvestres (Psittaciformes, Piciformes e Passerifomes) no estado do Ceará. In A etnozoologia no Brasil: importância, status atual e perspectivas. Edited by Alves RRN, Souto WMS, Mourão JS. Recife: Nuppea; 2010:381-402.

12. Bezerra DMM, Araujo HFP, Alves RRN: The use of wild birds by rural communities in the semi-arid region of Rio Grande do Norte State, Brazil. Bioremediation, Biodiversity and Bioavailability 2011, 5:117-120.

13. Bezerra DMM, Araujo HFP, Alves RRN: Captura de aves silvestres no semiárido brasileiro: técnicas cinegéticas e implicações para a conservação. Tropical Conservation Science 2012, 5:50-66.

14. Fernandes-Ferreira $\mathrm{H}$, Mendonça SV, Albano C, Ferreira FS, Alves RRN: Hunting use and conservation of birds in Northeast Brazil. Biodivers Conservation 2012, 21:221-244.

15. Vargas-Clavijo M, Costa-Neto EM: Los lipiadores de los cielos: factos y folclor de los zopilotes, aves dueñas del imaginario latinoamericano. UEFS Editora: Feira de Santana; 2008.

16. Alves RRN: Relationships between fauna and people and the role of ethnozoology in animal conservation. Ethnobiology and Conservation 2012, 1:1-69.

17. Hanazaki N, Alves RRN, Begossi A: Hunting and use of terrestrial fauna used by Caiçaras from the Atlantic Forest coast (Brazil). J Ethnobiol Ethnomed 2009, 5:1-8.

18. Costa-Neto EM: As corujas e o homem. Ciência Hoje 1999, 26:74-76.

19. Costa-Neto EM, Oliveira MV: Cockroach is good for asthma: zootherapeutic practices in northeastern Brazil. Human Ecology Review 2000, 7:41-51.

20. Alves RRN, Alves HN: The faunal drugstore: animal-based remedies used in traditional medicines in Latin America. J Ethnobiol Ethnomed 2011, 7:1-43.

21. Ferreira FS, Brito SV, Ribeiro SC, Almeida WO, Alves RRN: Zootherapeutics utilized by residents of the community PoçoDantas, Crato-CE, Brazil. J Ethnobiol Ethnomed 2009, 5:1-10.

22. Léo Neto NA, Brooks SE, Alves RNN: From Eshu to Obatala: animals used in sacrificial rituals at Candomblé "terreiros" in Brazil. J Ethnobiol Ethnomed 2009, 5:1-10.

23. Barbosa JAA, Alves RRN: "Um chá de que?" - animais utilizados no preparo tradicional de bebidas medicinais no agreste paraibano. Biofar 2010, 4:1-12.

24. Léo Neto NA, Alves RRN: A natureza sagrada do candomblé: análise da construção mística acerca da natureza em terreiros de candomblé no nordeste do Brasil. Interciência 2010, 35:568-574.

25. Alves RRN, Rosa IL, Léo Neto NA, Voeks R: Animals for the gods: magical and religious faunal use and trade in Brazil. Human Ecol 2012, 40:751-780.

26. Santos IB, Costa-Neto EM: Estudo etnoornitológico em uma região do semi-árido do Estado da Bahia, Brasil. Sitientibus Série Ciências Biologicas 2007, 7:273-288

27. Marques JGW: Da gargalhada ao pranto, Inserção Etnoecológica da vocalização de aves em ecossistemas rurais do Brasil. Tese. Feira de Santana: Universidade Estadual de Feira de Santana; 1999.

28. Araujo HFP, Lucena RFP, Mourão JS: Prenúncio de chuvas pelas aves na percepção de moradores de comunidades rurais no município de Soledade-PB, Brasil. Interciencia 2005, 30:764-769.

29. Marques JGW: O pássaro sagrado e o cavalo do cão (biodiversidade, etnoecologia e catolicismo popular no Brasil). Tese de Pós-Doutorado: Universidade Estadual de Campinas - UNICAMP - NEPAM; 2005.
30. Farias GB, Alves AGC, Marques JGW: Mythological relations between the "lavandeira" birds Fluvicolanegenta and Motacillaalba in Northeast Brazil and Northwest Spain: Possible cultural implications for conservation. J Ethnobiol 2010, 30:240-251.

31. Marques JGW: Pescando pescadores: etnoecologia abrangente no baixo São Francisco. São Paulo: NUPAUB-USP; 1995

32. Alves RRN, Rosa IL: From cnidarians to mammals: the use of animals as remedies in fishing communities in NE Brazil. J Ethnopharmacology 2006, 107:82-103

33. Alves RRN, Rosa IL: Zootherapy goes to town: the use of animal-based remedies in urban areas of NE and N Brazil. J Ethnopharmacol 2007, 113:541-555.

34. Alves RRN, Rosa IL: Zootherapeutic practices among fishing communities in North and Northeast Brazil: a comparison. J Ethnopharmacol 2007, 111:82-103.

35. Alves RRN, Rosa IL, Santana GG: The role of animal-derived remedies as complementary medicine in Brazil. Bioscience 2007, 57:949-955.

36. Alves RRN, Soares TC, Mourão JS: Uso de animais medicinais na comunidade de Bom Sucesso, Soledade, estado da Paraíba, Brasil. Sitientibus Série Ciências Biologicas 2008, 8:142-147.

37. Alves RRN: Fauna used in popular medicine in Northeast Brazil. J Ethnobiol Ethnomed 2009, 5:1-11.

38. Ferreira FS, Brito SV, Ribeiro SC, Almeida WO, Alves RRN: Animal-based folk remedies sold in public markets in Crato and Juazeiro do Norte, Ceará, Brazil. BMC Complementary and Alternative Medicine 2009, 9:1-8.

39. Oliveira ES, Torres DF, Brooks SE, Alves RRN: The medicinal animal markets in the metropolitan region of Natal City, northeastern Brazil. J Ethnopharmacol 2010, 130:54-60.

40. Souto WMS, Mourão JS, Barboza RRD, Alves RRN: Paralles between zootherapeuticpratices in etnoveterinary and human compllementary medicine in northeastern Brazil. J Ethnopharmacol 2011, 134:753-767.

41. Kizungu B, Ntabaza M, Mburunge M: Ethno-ornithology of the tembo in eastern DRC (formes Zaire): parte one, Kalehe zone. African Study Monographs 1998, 19:103-113.

42. Balderas AJC, Salas JAG, Velasco AG, Rojas JIG: Aprovechamiento de las aves cinegéticas, de ornato y canoras de Nuevo León, México. CienciaUanl 2001, 4:462-469.

43. Apaza L, Godoy R, Wilkie D, Byron E, Huanca T, Leonard WR, Peréz E, ReyesGarcia V, Vadez V: Markets and the use of wild animal for tradicional medicine: a case study aming the Tsimane Amerindians of the bolivian rain forest. J Ethnobio/ 2003, 23:47-64.

44. Mahawar MM, Jaroli DP: Animals and their products utilized as medicines by the inhabitants surrounding the Ranthambhore National Park India. J Ethnobiol Ethnomed 2006, 2:1-5.

45. Mahawar MM, Jaroli DP: Traditional knowledge on zootherapeutic uses by the Saharia tribe of Rajasthan, India. J Ethnobiol Ethnomed 2007, 3:1-6.

46. Mahawar MM, Jaroli DP: Traditional zootherapeutic studies in India: a review. J Ethnobiol Ethnomed 2008, 4:1-12.

47. Ceríaco LMP: A review of fauna used in zootherapeutic remedies in Portugal: historical origins, current uses, and implications for conservation. In Animals in Traditional Folk Medicine: Implications for conservation. Volume 1. Edited by Alves RRN, Rosa IL. Heidelberg/New York/ Dordrecht/London: Springer; 2013:317-345.

48. Benítez $\mathrm{G}$ : Animals used for medicinal and magico-religious purposes in western Granada Province, Andalusia (Spain). J Ethnopharmacol 2011, 137:1113-1123.

49. Chakravorty J, Meyer-Rochow B, Ghosh S: Vertebrates used for medicinal purposes by members of the Nyishi and Galo tribes in Arunachal Pradesh (North-East India). J Ethnobiol Ethnomed 2011, 7:1-14.

50. Fleming-Moran M: The folk view of natural causation and disease in Brazil and its relation to tradicional curing practices. Bol Mus Para Emílio Göeldi 1992, 8:65-156.

51. Begossi A, Braga FMS: Food taboos and folk medicine among fishermen from the Tocatins Riv. Amazoniana 1992, 12:101-118.

52. Costa-Neto EM: Tradicional use and sale of animals as medicines in Feira de Santana city, Bahia, Brazil. Indigenous Knowledge Development Monitor 1999, 7:6-9.

53. Pinto AAC, Maduro CB: Produtos e subprodutos da medicina popular comercializados na cidade de Boa Vista, Roraima. Acta Amazonica 2003, 33:281-290. 
54. Andrade JN, Costa-Neto EM: Primeiro registro da utilização medicinal de recursos pesqueiros na cidade de São Félix, Estado da Bahia, Brasil. Acto Sci Biol Sci 2005, 27:177-183.

55. Martínez FG, González RS, Velázquez RS: Aves com atributos pronosticadores, medicinales y mágico-religiosos entre lostojolabales (TojolWinik'otik) delejidosaltillo, las margaritas, Chipas. El canto del Centzontle 2010, 1:190-203.

56. Soewu DA, Adekanola TA: Traditional-Medical Knowledge and perception of Pangolins (Manissps) among the Awori People, Southwestern Nigeria. J Ethnobiol Etnhomed 2011, 7:1-11.

57. Costa-Neto EM, Alves RRN: Estado da arte da zooterapia popular no Brasil. In Zooterapia: os animais na medicina popular brasileira. Edited by CostaNeto EM, Alves RRN. Recife: Nupeea; 2010:15-54.

58. Barrera-Bassols N, Toledo VM: Ethnoecology of the Yucatec Maya: symbolism, knowledge and management of natural resources. J Latin American Geography 2005, 4:9-41.

59. Hanazaki N, Mazzeo R, Souza VC: O conhecimento local e a diversidade de diversidades. In Atualidades em Etnobiologia e Etnoecologia. 3rd edition. Edited by Kubo RR, Bassi JB, Souza GC, Alencar NL, Medeiros PM, Albuquerque UP. Recife: Nupeea; 2006:200-209.

60. Instituto Brasileiro de Geografia E Estatística (IBGE): 2010. http://sit.mda.gov br/download.php?ac=obterDadosBas\&m=2403806

61. Ministério do Meio Ambiente (MMA): Panorama da desertificação no Estado do Rio Grande do Norte. Brasília: Ministério do Meio Ambiente; 2005.

62. Bezerra Júnior JGO, Silva NM: Caracterização geoambiental da microrregião do Seridó Oriental do Rio Grande do Norte. Holos 2007, 2:78-91.

63. Varella-Freire AA: A caatinga hiperxerófila Seridó, a sua caracterização e estratégias para a sua conservação. São Paulo: Academia de Ciências do Estado de São Paulo - ACIESP; 2002.

64. Santana JAS, Souto SJ: Diversidade e estrutura fitossociológica da Caatinga na Estação Ecológica do Seridó-RN. Rev Biol Cienc da Terra 2006, 6:232-242.

65. Diegues AC, Arruda RSV: Saberes tradicionais e biodiversidade no Brasil. Brasília: Ministério do Meio Ambiente; São Paulo: USP; 2001.

66. Biernacki PE, Waldorf D: Snowball sampling problems and techniques of chain referral sampling. Sociological Methods and Research 1981, 10:141-163.

67. Mello LC: Antropologia Cultural. Vozes: Iniciação, teoria e temas. Petrópolis; 1986.

68. Stebbins RA: Fitting in: the researcher as learner and parcipant. Quality and Quanty 1987, 21:103-108.

69. Perlo BV: A field guide to the birds of Brazil. New York: Oxford University Press; 2009.

70. Ridgely RS, Tudor G: Field guide to the songbirds of South America: the passarines. Austin: University of Texas Press; 2009.

71. Silveira LF, Straube FC: Aves ameaçadas de extinção no Brasil. In Livro vermelho da fauna brasileira ameaçada de extinção. Edited by Machado $A B$ Drummond GM, Paglia AP. Brasil: 1a ed. Ministério do Meio Ambiente, Brasília; 2008:379-678.

72. International Union for Conservation of Nature (IUCN): Red List of Threatened Species. 2012. Version 2012.2 [www.iucnredlist.org]

73. Marques JGW: O sinal das aves: uma tipologia sugestiva para uma Etnoecologia com bases semióticas. In Atualidades em Etnobiologia e Etnoecologia. 1st edition. Edited by Albuquerque UPA, Alves AGC, Silva ACBL, Silva VA, Albuquerque UPA, Alves AGC, Silva ACBL, Silva VA. Recife: Nupeea; 2006:87-108.

74. Ribeiro GC, Pereira JPR, Docio L, Alarcon DT, Schiavetti A: Zooterápico utilizados no Sul da Bahia. In Zooterapia: os animais na medicina popular brasileira. Edited by Costa-Neto EM, Alves RRN. Recife: Nupeea; 2010:223-241.

75. Silva NLG, Ferreira FS, Coutinho HDM, Alves RRN: Zooterápicos utilizados em comunidades rurais do município de Sumé, Paraíba, Nordeste do Brasil. In Zooterapia: os animais na medicina popular brasileira. 2nd edition. Edited by Costa-Neto EM, Alves RRN. Recife: Nuppea: Série: Estudos \& Avanços; 2010:245-267.

76. Ferreira FS, Albuquerque UP, Coutinho HDM, Almeida WO, Alves RRN: The trade in medicinal animals in northeastern Brazil. Evidence-based Complementary and Alternative Medicine 2012, 2012:1-20.

77. Ferreira FS, Brito SV, Fernandes-Ferreira H, Alves RRN: Prospecção biológica, recursos zooterápicos e sustentabilidade. In Zooterapia: os animais na medicina popular brasileira. 2nd edition. Edited by Costa-Neto EM, Alves RRN. Recife: Nuppea: Série: Estudos \& Avanços; 2010:143-157.
78. Alves RRN, Rosa IL: Animals in Traditional Folk Medicine: Implications for conservation. 1st edition. Heidelberg/New York/Dordrecht/London: Springer; 2013:491.

79. Alves RRN, Albuquerque UP: Animals as a source of drugs: bioprospecting and biodiversity conservation. In Animals in Traditional Folk Medicine: Implications for conservation. 1st edition. Edited by Alves RRN, Rosa IL. Heidelberg/New York/Dordrecht/London: Springer; 2013:67-89.

80. Yoganathan S, Nicolosi R, Wilson T, Handelman G, Scollin P, Tao R, Binford P, Orthoefer F: Antagonism of croton oil inflammation by topical emu oil in CD-1 Mice. Lipids 2003, 38:603-307.

81. Murari SK, Frey FJ, Frey BM, Gowda TV, Vishwanath BS: Use of Pavo cristatus feather extract for the better management of snakebites: Neutralization of inflammatory reactions. J Ethnopharmacol 2005, 99:229-237.

82. Ferreira FS, Brito SV, Costa JGM, Alves RRN, Coutinho HDM, Almeida WO: Is the body fato $f$ the lizard Tupinambis merianae effective against bacterial infections? J Ethnopharmacol 2009, 126:233-237.

83. Nikolaus G: Bird exploitation for tradicional medicine in Nigeria. J West African Ornithological Society 2001, 23:45-55.

84. Williams VL, Cunningham AB, Bruyns RK, Kemp AC: Birds of a feather: quantitative assessments of the diversity and levels of threat to birds used in African traditional medicine. In Animals in Traditional Folk Medicine: Implications for conservation. 1st edition. Edited by Alves RRN, Rosa IL. Heidelberg/New York/Dordrecht/London: Springer; 2013:383-420.

85. Araújo AM: Medicina rústica. São Paulo: Companhia Editora Nacional; 1977.

86. Costa-Neto EM: Healing with animals in Feira de Santana city, Bahia, Brazil. J Ethnopharmacol 1999, 65:225-230.

87. Silva MLV, Alves AGC, Almeida AV: A zooterapia no Recife (Pernambuco): uma articulação entre as práticas e a história. Biotemas 2004, 17:95-116.

88. Alves RRN, Vieira WLS, Santana GG: Reptiles used in traditional folk medicine: conservation implications. Biodiversity and Conservation 2008, 17:2037-2049.

89. Moura FBP, Marques JGW: Zooterapia popular na Chapada Diamantina: uma medicina incidental? Ciência e Saúde Coletiva 2008, 13:2179-2188.

90. Marques JGW: Aspestos ecológicos na etnoictiologia dos pescadores do complexo estuarino-lagunar Mundaú - Manguaba. Campina: Tese (Doutorado). UNICAMP; 1991.

91. Torres DF, Oliveira ES, Alves RRN, Casconcellos A: Etnobotânica e Etnozoologia em unidades de conservação: uso da biodiversidade na APA de Genipabu, Rio Grande do Norte, Brasil. Interciencia 2009, 34:623-629.

92. Major I, Sales LG Jr, Castro R: Aves da caatinga. Fortaleza: Demócrito Rocha, Associação Caatinga; 2004.

93. Colding J, Folke C: The relation among threatened species, their protection, and taboos. Conservation Ecology 1997, 1:1-19.

94. Toledo VM, Barrera-Bassols N: A etnoecologia: uma ciência pós-normal que estuda as sabedorias tradionais. In Etnobiologia e Etnoecologia: pessoas \& natureza na América Latina. Edited by Silva VA, Almeida ALS, Albuquerque UP. Recife: Nuppea; 2010:13-36.

95. Cadima Cl, Marçal Júnior O: Notas sobre etnoornitologia na comunidade do Distrito rural de Miraporanga, Uberlândia, MG. Bioscience Journal 2004, 20:81-91.

96. Almeida SM, Franchin AG, Marçal Júnior O: Estudo etnoornitológico no distrito rural de Florestina, município de Araguari, região do Triângulo Mineiro, Minas Gerais. Sitientibus Série Ciências Biológicas 2006, 6:26-36.

97. Alves RRN, Santana GG, Rosa IL: The role of animal-derived remedies as complementary medicine in Brazil. In Animals in Traditional Folk Medicine: Implications for conservation. 1st edition. Edited by Alves RRN, Rosa IL. Heidelberg/New York/Dordrecht/London: Springer; 2013:289-301.

98. Alves RRN, Lima JRF, Araújo HF: The live bird trade in Brazil and its conservation implications: an overview. Bird Conservation International 2012, 1:1-13.

doi:10.1186/1746-4269-9-3

Cite this article as: Bezerra et al:: Birds and people in semiarid northeastern Brazil: symbolic and medicinal relationships. Journal of Ethnobiology and Ethnomedicine 2013 9:3. 